
\title{
$\begin{array}{ll}\text { Research Square } & \begin{array}{l}\text { Preprints are preliminary reports that have not undergone peer review. } \\ \text { They should not be considered conclusive, used to inform clinical practice, } \\ \text { or referenced by the media as validated information. }\end{array}\end{array}$
}

\section{Elucidation of the Molecular Consequences of Two Unique p6Gag Mutations Derived from HIV-1 CRF07_BC-infected Patients}

\section{Zetao Cheng}

Southern Medical University

\section{Sherimay D. Ablan}

National Cancer Institute

\section{Eric O. Freed}

National Cancer Institute

\section{Haiying Wang \\ Southern Medical University}

\section{Shixing Tang ( $\nabla$ tamgshixing@smu.edu.cn )}

Southern Medical University

\section{Research}

Keywords: HIV-1, CRF07_BC, p6 protein, virus release, infectivity, replication, Gag processing, Alix, Tsg101

Posted Date: January 20th, 2020

DOl: https://doi.org/10.21203/rs.2.21304/v1

License: (c) (i) This work is licensed under a Creative Commons Attribution 4.0 International License. Read Full License 


\section{Abstract}

Background We previously observed that individuals infected with HIV-1 CRF07_BC showed slower disease progression than those infected with HIV-1 subtype B or CRF01_AE. CRF07_BC viruses carry two unique mutations in the p6 Gag protein: insertion of PTAPPE sequences downstream of the original Tsg101 binding domain, and deletion of a seven-amino-acid sequence ( 30 PIDKELY 36 ) that partially overlaps with the Alix binding domain. To further define the role of these mutations in virus release and replication, we introduced them into the HIV-1 proviral clone pNL4-3 for functional characterization.

Results We found that the seven-amino-acid deletion, but not the PTAPPE insertion, significantly decreased virus release, Gag processing, and virus infectivity. The seven-amino-acid deletion also resulted in a virus replication defect in both T-cell lines and peripheral blood mononuclear cells. We found that these defects were caused by the seven-amino-acid deletion in p6 Gag , especially deletion of Tyr-36 of p6 Gag , not the deletion of the overlapping p6* sequence in the HIV-1 GagPol protein. The $\mathrm{p} 6 \mathrm{Gag}$ deletion mutant was resistant to a dominant-negative Alix fragment, suggesting a loss of binding between $\mathrm{p} 6 \mathrm{Gag}$ and Alix.

Conclusions Our results indicate that the patient-derived seven-amino-acid deletion in p6 Gag of HIV-1 CRF07_BC virus affects virus release, infectivity and replication capacity by disrupting the interaction between HIV-1 p6 Gag and host protein Alix. These results may explain the slower disease progression observed in the subjects infected with HIV-1 CRF07_BC bearing this unique mutation.

\section{Background}

CRF07_BC, a circulating recombinant form (CRF) of human immunodeficiency virus type one (HIV-1), was first identified in 2000 and has become one of the most commonly transmitted viruses in China[1-3]. In 2007, Lin et al. described a unique deletion mutation of 7 amino acids (aa) ${ }_{30}$ PIDKELY $_{36}$ ) in the p6 ${ }^{\mathrm{Gag}}$ protein of HIV-1 CRF07_BC isolates [4]. This 7-aa region partially overlaps with the host ALG-2 interacting protein X (Alix) binding domain, YPXnL, and the 7-aa deletion variant ( $\triangle 7$ ) exclusively exists in HIV-1 CRF07_BC isolates [4, 5]. We previously reported that about 54\% of CRF07_BC sequences from the Los Alamos National Laboratory database and $92 \%$ of the sequences from CRF07_BC-infected men who have sex with men (MSM) carry this $\triangle 7$ mutation[5]. In addition, we found that $26 \%$ of CRF07_BC viruses carry another insertion mutation of 6 aa, PTAPPE (insPTAP), in the p $6^{\text {Gag }}$ protein downstream of the PT/SAP motif, which serves as the binding site for the host protein tumor susceptibility gene 101 (Tsg101) [5]. CRF07_BC isolates with double mutation of $\Delta 7$ and insPTAP have been observed [5].

Previous studies indicated that patients infected with the CRF07_BC $\Delta 7$ variant exhibited lower viral loads and slower disease progression compared with individuals infected with HIV-1 subtype B or CRF01_AE [6-10]. Previous in vitro studies showed that HIV-1 isolates and the infectious clone of CRF07_BC with the $\Delta 7$ mutation displayed relatively lower replication capacity and slower replication kinetics than HIV-1 subtype B or Thai $B^{\prime}[7,8]$. Lin et al. found that the $\Delta 7$ mutation resulted in a defect in virus particle release and Gag processing, which in turn caused the accumulation of immature virions on the plasma membrane [8]. These results suggest that the $\Delta 7$ mutation in $p 6^{\text {Gag }}$ may affect the late events of the HIV-1 replication cycle and viral infectivity. However, the detailed molecular mechanisms contributing to these defects have not yet been investigated.

The HIV-1 Gag polyprotein precursor Pr55 ${ }^{\mathrm{Gag}}$ is sufficient for the assembly of virus-like particles (VLP). Once HIV-1 particles are released from infected cells, the Gag polyprotein is cleaved by the viral protease (PR) into several mature viral Gag proteins: matrix (MA), capsid (CA), nucleocapsid (NC), p6, and two spacer peptides, spacer 1 (SP1) and spacer 2 (SP2). PRmediated Gag processing triggers virus maturation and is essential for the conversion of the immature VLP to the infectious virion $[11,12]$. The $6^{\mathrm{Gag}}$ domain is required for virion budding-off from the plasma membrane through the action of its two 
highly conserved late domain motifs: PT/SAP and YPXnL $[11,12]$. The PT/SAP motif plays a major role in HIV-1 release by binding to Tsg101, a component of the endosomal sorting complex required for transport I (ESCRT-I) [11, 13-15]. Mutation of the PT/SAP motif results in a severe defect in virus budding $[16,17]$. The YPXnL motif regulates virus release by directly binding to the ESCRT-associated host protein Alix [18, 19]. Mutations that block YPXnL-Alix binding or overexpression of Alix disrupt virus replication and virion production [18-22]. Recently, Ajasin et al. reported that the CC chemokine ligand 2 (CCL2) can mobilize the Alix protein away from F-actin structures to the cytoplasm to enhance virion release in the presence of the LYPX motif in HIV-1 p6 ${ }^{\mathrm{Gag}}$ [23]. This new finding may explain the lower replication capacity and slower disease progression in subjects infected with HIV-1 subtype C (HIV-1C) due to the absence of LYPX motif in HIV-1C [24, 25]. In addition, the $\mathrm{C}$-terminal region of $\mathrm{p} 6$ overlaps with the $\mathrm{N}$-terminal region of pol, referred to as $\mathrm{p} 6^{*}$, as a result of a -1 ribosomal frameshift that occurs during translation of the gag open reading frame (ORF) [26-28]. Thus, the 7-aa PIDKELY deletion in $\mathrm{p}^{\mathrm{Gag}}$ also results in deletion of amino acids DRQGTVS in p6* (Fig. 1), which is 3 amino acids away from p6*-PR cleavage site. It has been reported that PR activation and/or PR-mediated maturation could be affected by the substitution of four amino acids, SFNF, near the p6*-PR cleavage site [29, 30].

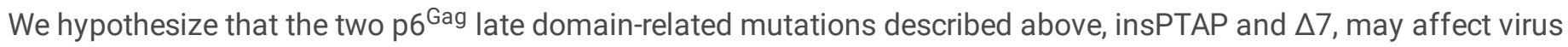
release by disrupting the interaction of p6 $^{\mathrm{Gag}}$ with Tsg101 and Alix, respectively. In addition, the overlapping 7-aa deletion of DRQGTVS in $6^{*}$ may affect the activity of HIV-1 PR. In this study, we introduced these mutations into a full-length, infectious HIV-1 proviral clone and characterized their role in virus release and replication. We found that the 7-aa deletion in p6 ${ }^{\mathrm{Gag}}(\Delta 7)$, but not the PTAP insertion (insPTAP), significantly decreased virus release, Gag processing, virus infectivity and

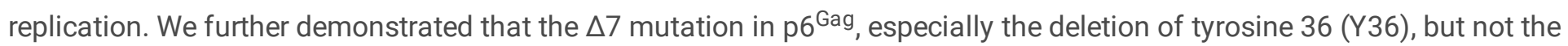
corresponding deletion mutation in $\mathrm{p} 6^{*}$, caused the observed defects by disrupting the interaction between HIV-1 p6 ${ }^{\text {Gag }}$ and Alix. These defects likely contribute to the slower disease progression observed in subjects infected with the HIV-1 CRF07_BC $\Delta 7$ variant.

\section{Results}

HIV-1 p6 Gag deletions impair virus release, infectivity and replication

The deletion of the Tsg101-binding motif PTAP ( $\triangle \mathrm{PTAP}$ ), insPTAP, $\Delta 7$, and P $\Delta 7 \mathrm{p} 6^{\text {Gag }}$ mutations (Fig. 1) were introduced into the full-length HIV-1 molecular clone pNL4-3. Wild type (WT) and mutant clones were transfected into 293T cells (Fig. 2a). Western blotting (WB) of cell and viral lysates was performed (Fig. 2a), and virus release and Gag processing efficiencies were quantified (Fig. 2b and c). By quantifying the p24 levels in virions relative to total Gag, we determined that deletion of the Tsg101-binding motif PTAP ( $\mathrm{P} T A P)$ severely impaired virus particle production (Fig. 2b), as reported previously $[16,17]$. However, the PTAPPE insertion (insPTAP) downstream of the original PTAP motif did not significantly affect virus release (Fig. 2b) except for a slightly increased tolerance to overexpression of Tsg101 (data not shown). The 7aa deletion $(\Delta 7)$ and the double mutation P $\Delta 7$ moderately inhibited virus production, to $\sim 77 \%$ and $\sim 62 \%$ of the WT level, respectively (Table 1, Fig. 2b). Similar results were obtained when the reverse transcriptase (RT) activity of culture supernatants was measured to determine the efficiency of virus release (Table 1). In addition, the efficiency of Gag processing was $\sim 73 \%, 73 \%, 52 \%$ and $37 \%$ for $\triangle \mathrm{PTAP}$, insPTAP, $\triangle 7$ and P $\Delta 7$, respectively (Fig. $2 \mathrm{c}$ ). These results demonstrate that the 7-aa deletion and the double mutation $\mathrm{P} \Delta 7$, but not the PTAP duplication in p6 ${ }^{\text {Gag, }}$, cause defects in virus release and Gag processing. 
Phenotypes of HIV-1 wild-type and p6 mutant virions

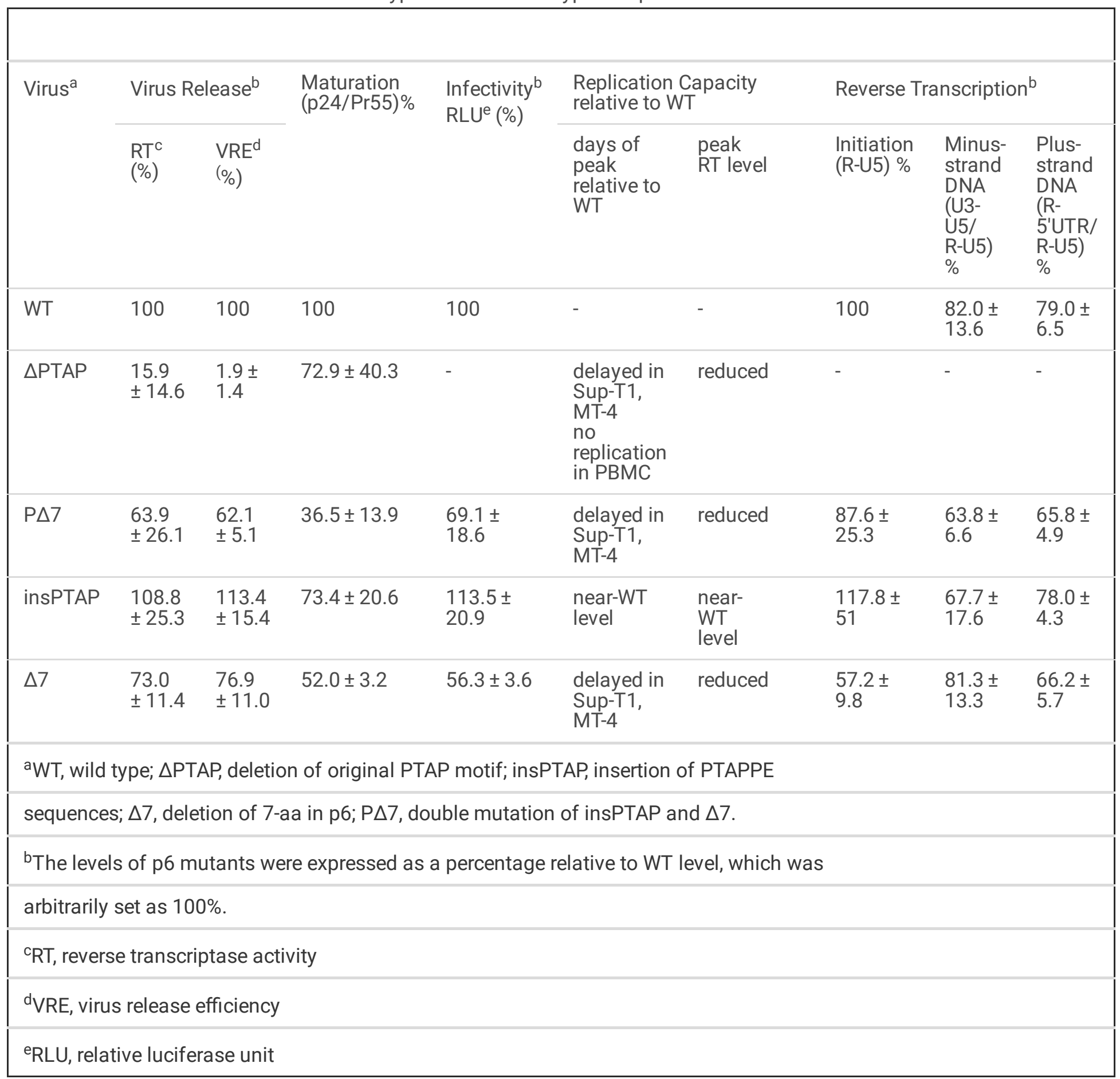

We further investigated the infectivity of these $\mathrm{p}^{\mathrm{Gag}}$ mutants and found that the insPTAP mutant showed levels of virus infectivity similar to those of WT in the TZM-bl system (Table 1). The infectivity of the mutant $\Delta 7$ and the double mutant $\mathrm{P} \Delta 7$ was $~ 56 \%$ and $69 \%$ WT level, respectively (Table 1). We next analyzed virus replication kinetics in the SupT1 and MT4 T-cell lines and in primary human peripheral blood mononuclear cells (PBMCs) from two donors. As expected, the $\triangle$ PTAP mutant showed very low-level and delayed replication kinetics in the T-cell lines (Fig. 3a and b), and no replication was observed in PBMCs (Fig. $3 \mathrm{c}$ and d). The insPTAP mutant was replication competent in both T-cell lines and PBMCs with no major difference from WT (Fig. 3). However, the $\Delta 7$ and P $\Delta 7$ mutants were defective in virus replication in SupT1 and MT4 T cells (Fig. 3a and b, Table 1), while low-level replication was also observed in PBMCs from two different donors (Fig. 3c and $d$, Table 1). The defects in viral replication were consistent with impairment of reverse transcription, in particular the 
initiation of reverse transcription (Fig. 4a), but not elongation (Fig. 4b), compared to WT. We found that the mutant insPTAP did not affect initiation of reverse transcription while the mutants P $\Delta 7$ and $\Delta 7$ reduced the initiation efficiency to $\sim 88 \%$ and $57 \%$ of WT level, respectively (Fig. 4a). These results demonstrate that the 7-aa deletion and the double mutation P $\Delta 7$, but not the PTAP duplication mutation in $\mathrm{p}^{\mathrm{Gag}}$, result in defects of virus infectivity and replication.

Deletion mutation in $\mathrm{p}^{\mathrm{Gag}}$ but not in $\mathrm{p} 6^{*}$ is responsible for the defects in virus release and Gag processing

The 7-aa PIDKELY deletion in p6 ${ }^{\text {Gag }}$ also results in deletion of amino acids DRQGTVS in p6* (Fig. 1). To determine the effects of the deletion mutation in $6^{\mathrm{Gag}}$ and $\mathrm{p} 6^{*}$ in virus release and Gag processing, we constructed several HIV-1 pNL4$3 / \mathrm{KFS}$ clones expressing $\mathrm{p}^{\mathrm{Gag}}{ }^{\mathrm{w}}$ with the 7-aa deletion $\left(\mathrm{Gag} \Delta 7\right.$ ) and $\mathrm{p} 6^{*}$ with the 7-aa deletion (GagPol $\Delta 7$ ). The GagPol construct expresses GagPol but does not express Gag, as the result of a 1-nucleotide insertion in the frameshift region that places gag and pol in the same ORF [31]. The Gag- and GagPol-expressing plasmids were co-transfected into 293T cells at a ratio of 15:1 to generate viral particles with a similar ratio of Gag to GagPol proteins as normal HIV-1 particles [31] (data not shown). We found that the deletion mutation in p6* did not significantly inhibit virus particle production or Gag processing (Fig. 5). In contrast, the deletion in $6^{\text {Gag }}$ resulted in a decrease in virus release and Gag processing efficiency to $\sim 47 \%$ of the WT level (Fig. 5b and c). Furthermore, the deletions in $6^{\mathrm{Gag}}$ and $\mathrm{p} 6^{*}$ did not affect the incorporation and processing of GagPol protein (data not shown). These results indicate that the 7-aa deletion in p6 ${ }^{\mathrm{Gag}}$, but not the deletion in the p6* domain, impairs virus release and Gag processing.

Tyrosine $36\left(\mathrm{Y}_{36}\right)$ in p6 ${ }^{\mathrm{Gag}}$ is critical for virus release and Gag processing

It has been reported that mutation Y36A in p6 ${ }^{\text {Gag }}$ markedly impaired virus particle production and Gag processing [20], demonstrating an important role of Y36 in controlling HIV-1 release and Gag processing. Consistent with these results, we observed that deletion of $\mathrm{Y}_{36}(\Delta \mathrm{Y})$ severely impaired virus production and Gag processing (Fig. 6a). The efficiency of virus release and Gag processing was 20\% (Fig. 6b) and 29\% (Fig. 6c) of the WT level, respectively. In contrast, the level of virus release and Gag processing for the 6-aa $\left({ }_{30} \mathrm{PIDKEL}_{35}\right.$ ) deletion mutation ( $\Delta 6$ ) was 80\% (Fig. 6b) and 108\% (Fig. 6c) relative to WT, respectively. These data indicate that $Y_{36}$ residue is critical in regulating virus release and maturation. Furthermore, the deletion of 6-aa $\left({ }_{30} \mathrm{PIDKEL}_{35}\right)$ sequences upstream of $\mathrm{Y}_{36}$ can partially restore the defects caused by $\mathrm{Y}_{36}$ deletion.

The deletion mutation in $\mathrm{p}^{\mathrm{Gag}}$ is resistant to overexpression of the Alix $\mathrm{V}$ domain

The Alix binding domain ${ }_{36} \mathrm{YPXnL}_{41}$ in $\mathrm{p6}^{\mathrm{Gag}}$ promotes virus release through the interaction between $\mathrm{HIV}-1$ p6 ${ }^{\mathrm{Gag}}$ and host protein Alix [18]. The central, so-called " $V$ " domain of Alix is responsible for binding the ${ }_{36} \mathrm{YPXnL}_{41}$ in p6 ${ }^{\mathrm{Gag}}$ [18, 21, 32]. As a result, overexpression of the Gag-binding $V$ domain of Alix (Alix $V$ ) potently disrupts particle budding by binding directly to HIV-1 Gag [21, 22, 33]. As expected, virus release of WT HIV-1 was significantly inhibited by overexpressing Alix V in 293T cells. Alix V/F676D protein, an Alix V variant that contains a Phe-to-Asp substitution in Alix residue 676 that abrogates p6 binding [21], did not inhibit particle release (Fig. 6a and b). Notably, overexpression of Alix $V$ did not affect virus release for the three p $6^{\mathrm{Gag}}$ mutants analyzed: $\Delta \mathrm{Y}, \Delta 6$, or $\Delta 7$ (Fig. $6 \mathrm{a}$ and b), indicating that these mutations prevent the interaction between $\mathrm{p} 6^{\mathrm{Gag}}$ and Alix. These data suggest that the deletion mutations in $\mathrm{p} 6^{\mathrm{Gag}}$ inhibit virus release by disrupting the binding of $p 6^{\mathrm{Gag}}$ and Alix protein.

\section{Discussion}

HIV-1 CRF07_BC originated from co-infection or superinfection of HIV-1 subtype B' and C [1, 34, 35]. Now it is becoming increasingly prevalent and is one of the most common CRFs in China [36-39]. Previous studies showed slower disease progression in subjects infected with CRF07_BC than subtype B or CRF01_AE $[6,8,10,40]$. Further investigation indicated 
that the above clinical findings may be associated with the deletion of 7 -aa $\left({ }_{30} \mathrm{PIDKELY}_{36}\right)$ in p6 ${ }^{\mathrm{Gag}}[6,8]$. In this study, we characterized the biological significance of two unique patient-derived mutations in p6 ${ }^{\mathrm{Gag}}$, i.e., PTAPPE insertion and 7-aa $\left({ }_{30}\right.$ PIDKELY $\left._{36}\right)$ deletion, from HIV-1 CRF07_BC-infected subjects. Our results show that the 7-aa deletion, not the PTAPPE insertion, moderately reduce virus release and Gag processing, and result in defects of infectivity and replication in both Tcell lines and PBMCs by disrupting the interaction between $\mathrm{p} 6^{\mathrm{Gag}}$ and the host Alix protein. Our study provides further evidence for the important role of the interaction between HIV-1 p $6^{\text {Gag }}$ protein and Alix binding domain in regulating virus release, Gag processing and replication, which in turn may explain at the molecular level the slower disease progression observed in individuals infected with CRF07_BC with the unique 7-aa deletion mutation in p6 ${ }^{\mathrm{Gag}}$.

The primary role of HIV-1 $\mathrm{p}^{\mathrm{Gag}}$ is to regulate virus budding by recruiting the ESCRT apparatus through the interaction between the late $(L)$ domains of $\mathrm{p}^{\mathrm{Gag}}$ and host factors Tsg101 and Alix to catalyze the membrane fission reaction that allows the virus to pinch off from the plasma membrane [11]. The two L domains in HIV-1 p6 ${ }^{\text {Gag }}$ are the Tsg101-binding site, ${ }_{7} \mathrm{PTAP}_{10}$, and the Alix-binding site, ${ }_{36} \mathrm{YPLASL}_{41}$. Insertions into, or duplication of, the PTAP motif could enhance the

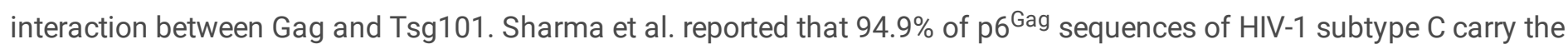
duplication of the PTAP motif. They confirmed that duplication of the PTAP motif enhances virus replication fitness, but not virus release of HIV-1, by binding the Tsg101 protein with a higher affinity [41]. PTAP duplication is usually observed in HIV1 strains with drug resistance mutations [42-45]. Martins et al. demonstrated that PTAP duplication enhances virus infectivity by increasing PR-mediated processing between NC and p6 in the presence of PR mutations and PR inhibitors (PIs) [31]. Martins et al. also found that the PTAP duplication did not increase virus release or the incorporation of pol products in virions. Tamiya et al. demonstrated that the PTAP insertion near Gag cleavage sites could restore the replication competence of multi-PI-resistant HIV-1 variants by enhancing the otherwise compromised enzymatic activity of mutant PR [45]. In this study, we demonstrated that the PTAP duplication alone does not affect virus release, infectivity or replication. These results are consistent with those obtained in previous studies and indicate that the major role of PTAP duplication may be to restore the replication capability in the presence of drug resistance mutations.

The HIV-1 p6 ${ }^{\text {Gag }}$ protein interacts with the ESCRT-I component Tsg101 and Alix, which in turn recruit ESCRT-III [11, 19]. Although the Tsg101-binding PTAP motif is more critical for HIV-1 release than the Alix-binding YPXL motif, the Alix binding domain is also required for optimal virus budding [18] and replication [20]. Previous studies have defined the critical role of

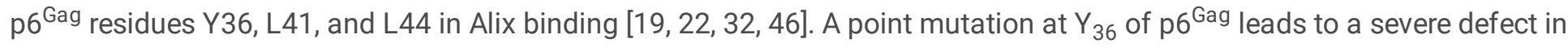
HIV-1 budding and Gag processing[18-20,32]. Fujii et al. proposed that, because the Y36A mutation had a more severe phenotype than other p6 Alix-binding site mutations, the Y36A mutation may not simply block the p6-Alix interaction, but could affect $\mathrm{p} 6$ folding and the upstream interaction with Tsg101[20]. In our study, we further confirmed the profound impact of deleting $Y_{36}$ on virus release, to about $20 \%$ of WT levels. Interestingly, compared with the severe defect exhibited by the $\mathrm{Y}_{36}$ deletion mutant, the 7-aa deletion ${ }_{30} \mathrm{PIDKELY}_{36}$ only moderately affected virus release and replication while deletion of the 6-aa $\left({ }_{30} \mathrm{PIDKEL}_{35}\right)$ did not significantly impair virus budding or Gag processing. Our results indicate that the deletion of the 6-aa ${ }_{30} \mathrm{PIDKEL}_{35}$ may partially neutralize the defect caused by $\mathrm{Y}_{36}$ deletion, and suggest the importance of optimal structure and conformation of the $\mathrm{p} 6$ domain of Gag. In fact, it is not uncommon that mutation at $Y_{36}$ and flanking amino acids could rescue viral defects. For example, the mutants Y36S/L44H and Y36S /L44R, exhibit WT levels of virus release in Hela and Jurkat cells, whereas the Y36A mutant impairs particle production by $\sim 5$ fold [20]. Fujii et al. also found several compensatory mutations in the putative revertant isolates, such as Y36A/L41I mutant [20]. Our study also indicated that PTAP duplication coupled with the 7-aa deletion in p $^{\mathrm{Gag}}$ may further interfere with the global folding of $\mathrm{p} 6$ and result in severe defects in particle release, Gag processing and virus replication.

It is noteworthy that deletion mutations in $\mathrm{p}^{\mathrm{Gag}}$ also result in amino-acid changes in $\mathrm{p} 6^{*}$ in the overlapping pol ORF. Several studies have reported that mutations upstream or downstream of the PR region potentially affect PR activity and Gag processing [47-50]. Wondrak et al. demonstrated that insertion of Alanine into the p6-PR cleavage site (from Phe-Pro

Page 6/18 
to Phe-Ala-Pro) severely impaired the autoprocessing of PR [51]. Chiu et al. reported that removal of the entire $6^{*}$ region did not affect incorporation of GagPol into virions, but abrogated viral infectivity [52]. In our study, the 7-aa deletion in p6* is 3aa (Phe-Ser-Phe) away from the p6-PR cleavage site. Our results showed that the corresponding deletion mutation in p6* did not influence virus release, but moderately decreased Gag processing. In addition, the deletion mutations in p6 ${ }^{\mathrm{Gag}}$ or $p 6^{*}$ did not affect the expression and incorporation of virion-associated reverse transcriptase (RT) or integrase (IN) (data not shown). Our results are consistent with those of Chiu et al., and indicated that deletion mutations in p ${ }^{*}$ have only a modest effect on PR-mediated Gag processing [52].

\section{Conclusion}

In summary, in this study we characterized two patient-derived mutations, a PTAPPE insertion and a PIDKELY deletion, in the p6 domain of HIV-1 Gag and the corresponding deletion in HIV-1 p6*. Our results demonstrated defects induced by the 7-aa deletion mutation in $\mathrm{p}^{\mathrm{Gag}}$ on virus release, Gag processing, infectivity and replication kinetics, due, at least in part, to disruption of the p6-Alix interaction. Our results provide further evidence about the importance of the intact p6 protein and its optimal conformation in regulating virus replication and infectivity. Our findings help define the molecular mechanism regarding the association between the unique 7-aa deletion mutation in $\mathrm{p}^{\mathrm{Gag}}$ and the slower disease progression observed in subjects infected with the 7 mutant CRF07_BC. It is noteworthy that the two patient-derived mutations in p6 ${ }^{\text {Gag }}$ only moderately affect virus replication, which in turn may confer a selective advantage and increase the prevalence of HIV-1 CRF07_BC with this unique mutation. Further study is needed to evaluate the virus replication capability and virus fitness by using the virus isolates with the 7-aa deletion in $\mathrm{p} 6^{\mathrm{Gag}}$.

\section{Methods}

\section{Plasmids}

The molecular clone pNL4-3 [53] and the envelope (env)(-) derivative pNL4-3/KFS [54] of HIV-1 were obtained through the $\mathrm{NIH}$ AIDS Reagent Program. Patient-derived mutations in $\mathrm{p}^{\mathrm{Gag}}$ were introduced by polymerase chain reaction (PCR)-based mutagenesis as previously reported [55] into pNL4-3 to generate the following three mutants: PTAPPE insertion (insPTAP), 7-aa $\left({ }_{30}\right.$ PIDKELY $_{36}$ ) deletion (D7), and the double mutant (PD7) containing both insPTAP and D7 (Fig. 1a, b). A PTAP motif deletion mutant (DPTAP) was used as a control for measuring defective virus release (Fig. 1b). Three additional mutations were introduced into pNL4-3/KFS: DY, in which Y36 of p6 ${ }^{\text {Gag }}$ was deleted; and D6 and D7, in which ${ }_{30} \mathrm{PIDKEL}_{35}$ or ${ }_{30} \mathrm{PIDKELY}_{36}$ of $\mathrm{p}^{\mathrm{Gag}}$, respectively, were deleted. An additional set of mutants was constructed to express Gag and GagPol polyproteins with the D7 mutation in p6 ${ }^{\mathrm{Gag}}$ or p6*, respectively, by using the plasmids pR7WT-HA and pR7insFS, which express the Gag and GagPol polyproteins, respectively [31]. The D7 mutation in p6 ${ }^{\mathrm{Gag}}$ and $p 6^{*}$ was then introduced into pNL4-3/KFS. All the constructs were characterized by restriction digestion analysis and DNA sequencing. The plasmids that express the $\mathrm{V}$ domain of Alix (residues 364-716, Alix V) and the Alix V derivative containing the F676D mutation (Alix V/F676D) have been described [21, 22].

\section{Cell culture and transfection}

293T and TZM-bl cells were cultured in Dulbecco's modified Eagle's medium (DMEM) supplemented with 10\% (vol/vol) fetal bovine serum (FBS), $100 \mathrm{U} / \mathrm{ml}$ penicillin, $100 \mathrm{~g} / \mathrm{mL}$ streptomycin, and $2 \mathrm{mM} \mathrm{L-glutamine} \mathrm{(Gibco).} \mathrm{TZM-bl} \mathrm{is} \mathrm{a} \mathrm{HeLa-derived}$ indicator cell line that expresses luciferase following HIV-1 infection [56]. Sup-T1, MT-4 T-cells, and PBMCs were cultured in RPMI 1640 medium supplemented with 10\% (vol/vol) FBS, $100 \mathrm{U} / \mathrm{mL}$ penicillin, $100 \mathrm{~g} / \mathrm{ml}$ streptomycin, and $2 \mathrm{mM} \mathrm{L-}$ 
glutamine. PBMCs obtained from anonymous, de-identified NIH blood donors were activated in RPMI 1640 medium supplemented with interleukin-2 and phytohemagglutinin (PHA) prior to HIV-1 infection. Adherent cells were transfected with plasmid DNA using Lipofectamine 2000 (Invitrogen Corp. Carlsbad, CA) according to the manufacturer's recommendations. Cells and viruses were harvested $24 \mathrm{~h}$ post-transfection and used for further analysis.

\section{Virus release and maturation}

293T cells were transfected with WT or mutant pNL4-3 molecular clones using Lipofectamine 2000 transfection reagent. At $24 \mathrm{~h}$ post-transfection, virions were pelleted by ultracentrifugation. Both cell and virus pellets were lysed and immunoblotted with HIV-1 immunoglobulin (HIV-Ig) obtained from the NIH AIDS Reagent Program. Virus release efficiency was calculated as the amount of virion-associated p24 (CA) as a fraction of the total amount of Gag including cell-associated-p24 and Pr55 ${ }^{\mathrm{Gag}}$ plus virion-associated p24, or the RT activity of culture supernatants relative to WT level [17, 57]. Virus maturation was measured by Gag processing and expressed as a ratio of virion-associated p24 over Pr55Gag levels as described previously $[6,30]$.

\section{Virus replication and infectivity}

Multi-cycle replication assays were performed using the Sup-T1 or MT-4 T-cell lines, and PBMCs. Sup-T1 and MT-4 T cells were transfected using DEAE-dextran reagent $[57,58]$. PBMCs from multiple donors were infected with virus supernatants generated by transfecting 293T cells. Virus inputs were normalized by RT activity. Cells were infected by inoculation of HIV1 viruses for $2 \mathrm{~h}$ at $37 \mathrm{C}$. Virus replication was monitored by measuring RT activity as described previously [59]. Virus infectivity was monitored by measuring luciferase activity in TZM-bl cells infected with HIV-1 virus supernatants from 293T cells as described previously [31].

\section{Western blotting analysis}

293T cells were harvested at $24 \mathrm{~h}$ post-transfection. Virus-containing supernatants were collected and virus particles were pelleted by ultracentrifugation. Cells and virus pellets were lysed in a buffer containing $50 \mathrm{mM} \mathrm{Tris-HCl}(\mathrm{pH} 7.4), 150 \mathrm{mM}$ $\mathrm{NaCl}, 1 \mathrm{mM}$ EDTA, 0.5\% Triton X-100, and protease inhibitor cocktail (Roche Life Sciences, Basel, Switzerland). After denaturation, proteins were subjected to SDS-PAGE, transferred to a polyvinylidene fluoride (PVDF) membrane, and incubated with HIV-Ig. The membrane was then incubated with horseradish peroxidase (HRP)-conjugated secondary antibodies, and the chemiluminescence signal was detected by using Western Pico substrate (Thermo Scientific) or Western Femto substrate (Fdbio Science). Quantification of the protein band intensity was performed using ImageLab software (BioRad).

\section{Quantitative PCR analysis of reverse transcription}

Pseudotyped HIV-1 virions were produced by co-transfecting 293T cells with pNL4-3/KFS encoding WT or p6 ${ }^{\text {Gag }}$-mutant Gag and a vesicular stomatitis virus G (VSV-G)-expressing vector, pHCMV-G [60]. A total of $210^{5} 293$ T cells/well were then infected with pseudotyped HIV-1 virions equivalent to $2 \mathrm{ng}$ of $\mathrm{p} 24$. At $2 \mathrm{~h}$ post-infection, the culture supernatants were removed and replenished with fresh complete medium. The cells were cultured for another 40-48h. Total DNA was isolated using the QIAamp DNA Mini Kit (Qiagen) and used as the template to analyze initiation (R-U5), minus-strand transfer (U3- 
U5), plus-strand transfer (R-5'UTR) of HIV-1 reverse transcription using SYBR-green (TAKARA)-based qPCR and HIV-1 specific primers described previously [61]. The results were obtained from 3 independent experiments.

\section{Statistical analysis}

Statistics were calculated using SPSS Statistics 20. Unpaired t tests were performed and two-tailed $* P<0.05, * \star P<0.01$, and ${ }^{* *} \mathrm{P}<0.001$ were considered statistically significant.

\section{Abbreviations}

HIV-1: human immunodeficiency virus type one; CRF: circulating recombinant form; Alix: ALG-2 interacting protein X; Tsg101: tumor susceptibility gene 101; MSM: men who have sex with men; VSV-G: vesicular stomatitis virus G; ESCRT: endosomal sorting complex required for transport; CCL2: CC chemokine ligand 2; PBMC: peripheral blood mononuclear cell.

\section{Declarations}

\section{Acknowledgements}

Not applicable.

\section{Authors' contributions}

ZC: acquisition of data, analysis and interpretation of data, and drafting of manuscript. SA: acquisition of data. HW: conception and acquisition of data. EF: conception, design and finalizing manuscript, and ST: conception, design, drafting and finalizing manuscript. All authors read and approved the final manuscript.

\section{Funding}

This work was supported in part by funds from the National Natural Science Foundation of China (No. 31800146) and the Intramural Research Program of the Center for Cancer Research, National Cancer Institute, National Institutes of Health.

\section{Availability of data and materials}

The datasets used in the study are available from the corresponding author upon request.

\section{Ethics approval and consent to participate}

Not applicable. 
Not applicable.

\section{Competing interests}

The authors declare that they have no competing interests.

\section{Author details}

${ }^{1}$ Guangdong Provincial Key Laboratory of Tropical Disease Research, School of Public Health, Southern Medical University, Guangzhou 510515, China

${ }^{2}$ Virus-Cell Interaction Section, HIV Dynamics and Replication Program, Center for Cancer Research, National Cancer Institute, Frederick, MD 21702, USA

${ }^{3}$ Dermatology Hospital, Southern Medical University, Guangzhou, Guangdong, China.

\section{References}

1. Su L, Graf M, Zhang Y, von Briesen H, Xing H, Kostler J, Melzl H, Wolf H, Shao Y, Wagner R: Characterization of a virtually full-length human immunodeficiency virus type 1 genome of a prevalent intersubtype (C/B') recombinant strain in China. $J$ Virol 2000, 74:11367-11376.

2. Takebe Y, Liao H, Hase S, Uenishi R, Li Y, Li XJ, Han X, Shang H, Kamarulzaman A, Yamamoto N, et al: Reconstructing the epidemic history of HIV-1 circulating recombinant forms CRF07_BC and CRF08_BC in East Asia: the relevance of genetic diversity and phylodynamics for vaccine strategies. Vaccine 2010, 28 Suppl 2:B39-44.

3. Xin R, He X, Xing H, Sun F, Ni M, Zhang Y, Meng Z, Feng Y, Liu S, Wei J, Shao Y: Genetic and temporal dynamics of human immunodeficiency virus type 1 CRF07_BC in Xinjiang, China. J Gen Virol 2009, 90:1757-1761.

4. Lin YT, Lan YC, Chen YJ, Huang YH, Lee CM, Liu TT, Wong WW, Yang JY, Wang CT, Chen YM: Molecular epidemiology of HIV-1 infection and full-length genomic analysis of circulating recombinant form 07_BC strains from injection drug users in Taiwan. J Infect Dis 2007, 195:1283-1293.

5. Wu Y, Wang H, Ren X, Wan Z, Hu G, Tang S: HIV-1 CRF07_BC with a Seven Amino Acid Deletion in the gag p6 Region Dominates in HIV-1-Infected Men Who Have Sex with Men in China. AIDS Res Hum Retroviruses 2017, 33:977-983.

6. Huang SW, Wang SF, Lin YT, Yen CH, Lee CH, Wong WW, Tsai HC, Yang CJ, Hu BS, Lin YH, et al: Patients infected with CRF07_BC have significantly lower viral loads than patients with HIV-1 subtype B: mechanism and impact on disease progression. PLoS One 2014, 9:e114441.

7. Jiang YL, Bai WW, Qu FW, Ma H, Jiang RS, Shen BS: Construction and characterization of HIV type 1 CRF07_BC infectious molecular clone from men who have sex with men. $J$ Virol Methods 2016, 229:70-77.

8. Lin PH, Lai CC, Yang JL, Huang HL, Huang MS, Tsai MS, Yang CJ, Cheng CL, Su YC, Chang SF, et al: Slow immunological progression in HIV-1 CRF07_BC-infected injecting drug users. Emerg Microbes Infect 2013, 2:e83.

9. Song YH, Meng ZF, Xing H, Ruan YH, Li XP, Xin RL, Ma PF, Peng H, Shao Y: Analysis of HIV-1 CRF07_BC gag p6 sequences indicating novel deletions in the central region of p6. Arch Viro/ 2007, 152:1553-1558.

10. Liang Y, Han Z, Shui J, Cheng W, Zhong F, Cai Q, Wang H, Wu H, Xu H, Tang S: HIV-1 genotype is independently associated with immunodeficiency progression among Chinese men who have sex with men: an observational cohort 
study. HIV Med 2019.

11. Freed EO: HIV-1 assembly, release and maturation. Nature Reviews Microbiology 2015, 13:484-496.

12. Sundquist WI, Krausslich HG: HIV-1 Assembly, Budding, and Maturation. Cold Spring Harbor Perspectives in Medicine 2012, 2:a006924-a006924.

13. Garrus JE, von Schwedler UK, Pornillos OW, Morham SG, Zavitz KH, Wang HE, Wettstein DA, Stray KM, Cote M, Rich RL, et al: Tsg101 and the vacuolar protein sorting pathway are essential for HIV-1 budding. Cel/ 2001, 107:55-65.

14. Votteler J, Sundquist WI: Virus budding and the ESCRT pathway. Cell Host Microbe 2013, 14:232-241.

15. VerPlank L, Bouamr F, LaGrassa TJ, Agresta B, Kikonyogo A, Leis J, Carter CA: Tsg101, a homologue of ubiquitinconjugating (E2) enzymes, binds the L domain in HIV type 1 Pr55(Gag). Proc Natl Acad Sci U S A 2001, 98:7724-7729.

16. Demirov DG, Orenstein JM, Freed EO: The Late Domain of Human Immunodeficiency Virus Type 1 p6 Promotes Virus Release in a Cell Type-Dependent Manner. Journal of Virology 2002, 76:105-117.

17. Huang M, Orenstein JM, Martin MA, Freed EO: $\mathrm{p} 6 \mathrm{Gag}$ is required for particle production from full-length human immunodeficiency virus type 1 molecular clones expressing protease. $J$ Viro/ 1995, 69:6810-6818.

18. Fisher RD, Chung HY, Zhai Q, Robinson H, Sundquist WI, Hill CP: Structural and biochemical studies of ALIX/AIP1 and its role in retrovirus budding. Cell 2007, 128:841-852.

19. Strack B, Calistri A, Craig S, Popova E, Gottlinger HG: AIP1/ALIX is a binding partner for HIV-1 p6 and EIAV p9 functioning in virus budding. Cell 2003, 114:689-699.

20. Fujii K, Munshi UM, Ablan SD, Demirov DG, Soheilian F, Nagashima K, Stephen AG, Fisher RJ, Freed EO: Functional role of Alix in HIV-1 replication. Virology 2009, 391:284-292.

21. Lee S, Joshi A, Nagashima K, Freed EO, Hurley JH: Structural basis for viral late-domain binding to Alix. Nat Struct Mol Biol 2007, 14:194-199.

22. Munshi UM, Kim J, Nagashima K, Hurley JH, Freed EO: An Alix fragment potently inhibits HIV-1 budding: characterization of binding to retroviral YPXL late domains. J Biol Chem 2007, 282:3847-3855.

23. Ajasin DO, Rao VR, Wu X, Ramasamy S, Pujato M, Ruiz AP, Fiser A, Bresnick AR, Kalpana GV, Prasad VR: CCL2 mobilizes ALIX to facilitate Gag-p6 mediated HIV-1 virion release. Elife 2019, 8.

24. Fantuzzi L, Spadaro F, Vallanti G, Canini I, Ramoni C, Vicenzi E, Belardelli F, Poli G, Gessani S: Endogenous CCL2 (monocyte chemotactic protein-1) modulates human immunodeficiency virus type-1 replication and affects cytoskeleton organization in human monocyte-derived macrophages. Blood 2003, 102:2334-2337.

25. Kiguoya MW, Mann JK, Chopera D, Gounder K, Lee GQ, Hunt PW, Martin JN, Ball TB, Kimani J, Brumme ZL, et al: Subtype-Specific Differences in Gag-Protease-Driven Replication Capacity Are Consistent with Intersubtype Differences in HIV-1 Disease Progression. J Virol 2017, 91.

26. Brierley I, Dos Ramos FJ: Programmed ribosomal frameshifting in HIV-1 and the SARS-CoV. Virus Res 2006, 119:29-42.

27. Jacks T, Power MD, Masiarz FR, Luciw PA, Barr PJ, Varmus HE: Characterization of ribosomal frameshifting in HIV-1 gag-pol expression. Nature 1988, 331:280-283.

28. Karn J, Stoltzfus CM: Transcriptional and posttranscriptional regulation of HIV-1 gene expression. Cold Spring Harb Perspect Med 2012, 2:a006916.

29. Ludwig C, Leiherer A, Wagner R: Importance of protease cleavage sites within and flanking human immunodeficiency virus type 1 transframe protein p6* for spatiotemporal regulation of protease activation. J Virol 2008, 82:4573-4584.

30. Yu FH, Huang KJ, Wang CT: C-Terminal HIV-1 Transframe p6* Tetrapeptide Blocks Enhanced Gag Cleavage Incurred by Leucine Zipper Replacement of a Deleted p6* Domain. J Virol 2017, 91.

31. Martins AN, Waheed AA, Ablan SD, Huang W, Newton A, Petropoulos CJ, Brindeiro RD, Freed EO: Elucidation of the Molecular Mechanism Driving Duplication of the HIV-1 PTAP Late Domain. J Virol 2016, 90:768-779. 
32. Zhai Q, Fisher RD, Chung HY, Myszka DG, Sundquist WI, Hill CP: Structural and functional studies of ALIX interactions with YPX(n)L late domains of HIV-1 and EIAV. Nat Struct Mol Biol 2008, 15:43-49.

33. Chen C, Vincent O, Jin J, Weisz OA, Montelaro RC: Functions of early (AP-2) and late (AIP1/ALIX) endocytic proteins in equine infectious anemia virus budding. $J$ Biol Chem 2005, 280:40474-40480.

34. Feng Y, Takebe Y, Wei H, He X, Hsi JH, Li Z, Xing H, Ruan Y, Yang Y, Li F, et al: Geographic origin and evolutionary history of China's two predominant HIV-1 circulating recombinant forms, CRF07_BC and CRF08_BC. Sci Rep 2016, 6:19279.

35. Tee KK, Pybus OG, Li XJ, Han X, Shang H, Kamarulzaman A, Takebe Y: Temporal and spatial dynamics of human immunodeficiency virus type 1 circulating recombinant forms 08_BC and 07_BC in Asia. J Viro/ 2008, 82:9206-9215.

36. Chen ZW, Liu L, Chen G, Cheung KW, Du Y, Yao X, Lu Y, Chen L, Lin X, Chen Z: Surging HIV-1 CRF07_BC epidemic among recently infected men who have sex with men in Fujian, China. J Med Viro/ 2018, 90:1210-1221.

37. He X, Xing H, Ruan Y, Hong K, Cheng C, Hu Y, Xin R, Wei J, Feng Y, Hsi JH, et al: A comprehensive mapping of HIV-1 genotypes in various risk groups and regions across China based on a nationwide molecular epidemiologic survey. PLoS One 2012, 7:e47289.

38. Li L, Wei D, Hsu WL, Li T, Gui T, Wood C, Liu Y, Li H, Bao Z, Liu S, et al: CRF07_BC Strain Dominates the HIV-1 Epidemic in Injection Drug Users in Liangshan Prefecture of Sichuan, China. AIDS Res Hum Retroviruses 2015, 31:479-487.

39. Wu J, Guo H, Zhang J, Liu X, Ayoupu A, Shen Y, Miao L, Tang J, Lei Y, Su B: The Epidemic History of HIV-1 CRF07_BC in Hetian Prefecture and the Role of It on HIV Spreading in China. AIDS Res Hum Retroviruses 2017, 33:364-367.

40. Ma L, Guo Y, Yuan L, Huang Y, Sun J, Qu S, Yu X, Meng Z, He X, Jiang S, Shao Y: Phenotypic and genotypic characterization of Human Immunodeficiency Virus type 1 CRF07_BC strains circulating in the Xinjiang Province of China. Retrovirology 2009, 6.

41. Sharma S, Arunachalam PS, Menon M, Ragupathy V, Satya RV, Jebaraj J, Aralaguppe SG, Rao C, Pal S, Saravanan S, et al: PTAP motif duplication in the p6 Gag protein confers a replication advantage on HIV-1 subtype C. J Biol Chem 2018, 293:11687-11708.

42. Ibe S, Shibata N, Utsumi M, Kaneda T: Selection of human immunodeficiency virus type 1 variants with an insertion mutation in the p6(gag) and p6(pol) genes under highly active antiretroviral therapy. Microbiol Immuno/ 2003, 47:71-79.

43. Martins AN, Arruda MB, Pires AF, Tanuri A, Brindeiro RM: Accumulation of P(T/S)AP late domain duplications in HIV type 1 subtypes $B, C$, and $F$ derived from individuals failing ARV therapy and ARV drug-naive patients. AIDS Res Hum Retroviruses 2011, 27:687-692.

44. Peters S, Munoz M, Yerly S, Sanchez-Merino V, Lopez-Galindez C, Perrin L, Larder B, Cmarko D, Fakan S, Meylan P, Telenti A: Resistance to nucleoside analog reverse transcriptase inhibitors mediated by human immunodeficiency virus type 1 p6 protein. J Virol 2001, 75:9644-9653.

45. Tamiya S, Mardy S, Kavlick MF, Yoshimura K, Mistuya H: Amino acid insertions near Gag cleavage sites restore the otherwise compromised replication of human immunodeficiency virus type 1 variants resistant to protease inhibitors. $J$ Virol 2004, 78:12030-12040.

46. von Schwedler UK, Stuchell M, Muller B, Ward DM, Chung HY, Morita E, Wang HE, Davis T, He GP, Cimbora DM, et al: The protein network of HIV budding. Cell 2003, 114:701-713.

47. Engelman A, Englund G, Orenstein JM, Martin MA, Craigie R: Multiple effects of mutations in human immunodeficiency virus type 1 integrase on viral replication. J Virol 1995, 69:2729-2736.

48. Liao WH, Wang CT: Characterization of human immunodeficiency virus type 1 Pr160 gag-pol mutants with truncations downstream of the protease domain. Virology 2004, 329:180-188.

49. Quillent C, Borman AM, Paulous S, Dauguet C, Clavel F: Extensive regions of pol are required for efficient human immunodeficiency virus polyprotein processing and particle maturation. Virology 1996, 219:29-36.

50. Zybarth G, Carter C: Domains upstream of the protease (PR) in human immunodeficiency virus type 1 Gag-Pol influence PR autoprocessing. J Virol 1995, 69:3878-3884. 
51. Wondrak EM, Louis JM: Influence of flanking sequences on the dimer stability of human immunodeficiency virus type 1 protease. Biochemistry 1996, 35:12957-12962.

52. Chiu HC, Wang FD, Chen YM, Wang CT: Effects of human immunodeficiency virus type 1 transframe protein p6* mutations on viral protease-mediated Gag processing. J Gen Virol 2006, 87:2041-2046.

53. Adachi A, Gendelman HE, Koenig S, Folks T, Willey R, Rabson A, Martin MA: Production of acquired immunodeficiency syndrome-associated retrovirus in human and nonhuman cells transfected with an infectious molecular clone. J Virol 1986, 59:284-291.

54. Freed EO, Delwart EL, Buchschacher GL, Jr., Panganiban AT: A mutation in the human immunodeficiency virus type 1 transmembrane glycoprotein gp41 dominantly interferes with fusion and infectivity. Proc Natl Acad Sci U S A 1992, 89:70-74.

55. Kunkel TA, Roberts JD, Zakour RA: Rapid and efficient site-specific mutagenesis without phenotypic selection. Methods Enzymol 1987, 154:367-382.

56. Platt EJ, Wehrly K, Kuhmann SE, Chesebro B, Kabat D: Effects of CCR5 and CD4 cell surface concentrations on infections by macrophagetropic isolates of human immunodeficiency virus type 1. J Viro/ 1998, 72:2855-2864.

57. Freed EO, Orenstein JM, Buckler-White AJ, Martin MA: Single amino acid changes in the human immunodeficiency virus type 1 matrix protein block virus particle production. J Virol 1994, 68:5311-5320.

58. Novikova M, Adams LJ, Fontana J, Gres AT, Balasubramaniam M, Winkler DC, Kudchodkar SB, Soheilian F, Sarafianos SG, Steven AC, Freed EO: Identification of a Structural Element in HIV-1 Gag Required for Virus Particle Assembly and Maturation. MBio 2018, 9.

59. Willey RL, Smith DH, Lasky LA, Theodore TS, Earl PL, Moss B, Capon DJ, Martin MA: In vitro mutagenesis identifies a region within the envelope gene of the human immunodeficiency virus that is critical for infectivity. $J$ Viro/ 1988, 62:139-147.

60. Yee JK, Friedmann T, Burns JC: Generation of high-titer pseudotyped retroviral vectors with very broad host range. Methods Cell Biol 1994, 43 Pt A:99-112.

61. Buckman JS, Bosche WJ, Gorelick RJ: Human immunodeficiency virus type 1 nucleocapsid zn(2+) fingers are required for efficient reverse transcription, initial integration processes, and protection of newly synthesized viral DNA. J Virol 2003, 77:1469-1480.

\section{Figures}




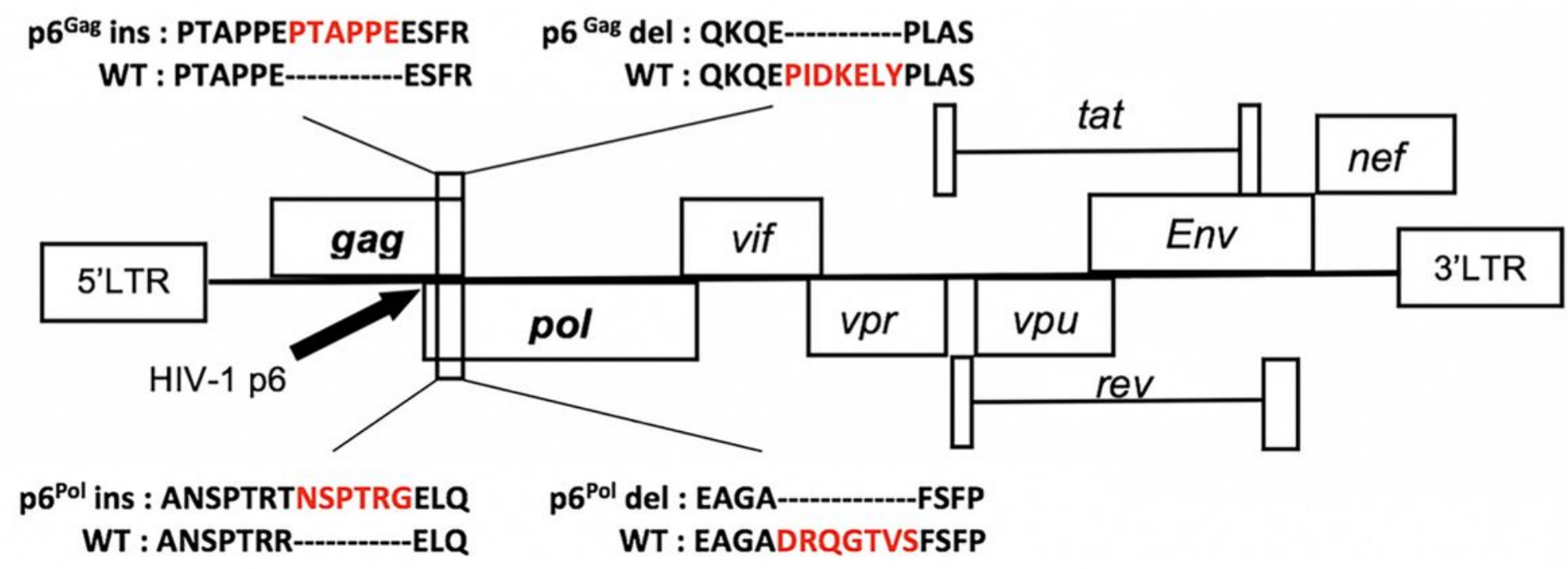

b

\begin{tabular}{|c|c|}
\hline P6 Mutants & Amino acid sequences of $p 6^{\text {Gag }}$ \\
\hline WT & LQSRPEPTAPPE- - - - - -ESFRFGEETTTPSQKQE|PIDKELYPLASLRSLFGSDPSSQ \\
\hline$\triangle \mathrm{PTAP}$ & QQE PIDKELY PLASLRSLFGSDPSSQ \\
\hline insPTAP & LQSRPEPTAPPEPTAPPEESFRFGEETTTPSQKQE PIDKELY PLASLRSLFGSDPSSQ \\
\hline$\Delta 7$ & LQSRPEPTAPPE- - - - - -ESFRFGEETTTPSQKQE - - . \\
\hline $\mathrm{P} \Delta 7$ & LQSRPEPTAPPEPTAPPEESFRFGEETTTPSQKQE $-\cdots$ \\
\hline
\end{tabular}

Figure 1

Schematic of the HIV-1 genome and p6 mutants. a The HIV-1 genome is shown with an expanded view of p6 mutations including PTAPPE insertion and PIDKELY deletion in p6Gag, as well as NSPTRG insertion and DRQGTVS deletions in p6Pol. b HIV-1 p6Gag mutants. These mutants were generated using the HIV-1 full-length proviral clone pNL4-3, including PTAPPE

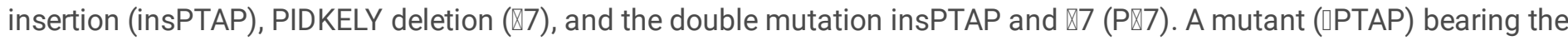
deletion of the original PTAP motif was constructed and used as a control for deficiency of virus release. Sequences of mutations are highlighted and compared with HIV-1 wild-type (WT). 
a
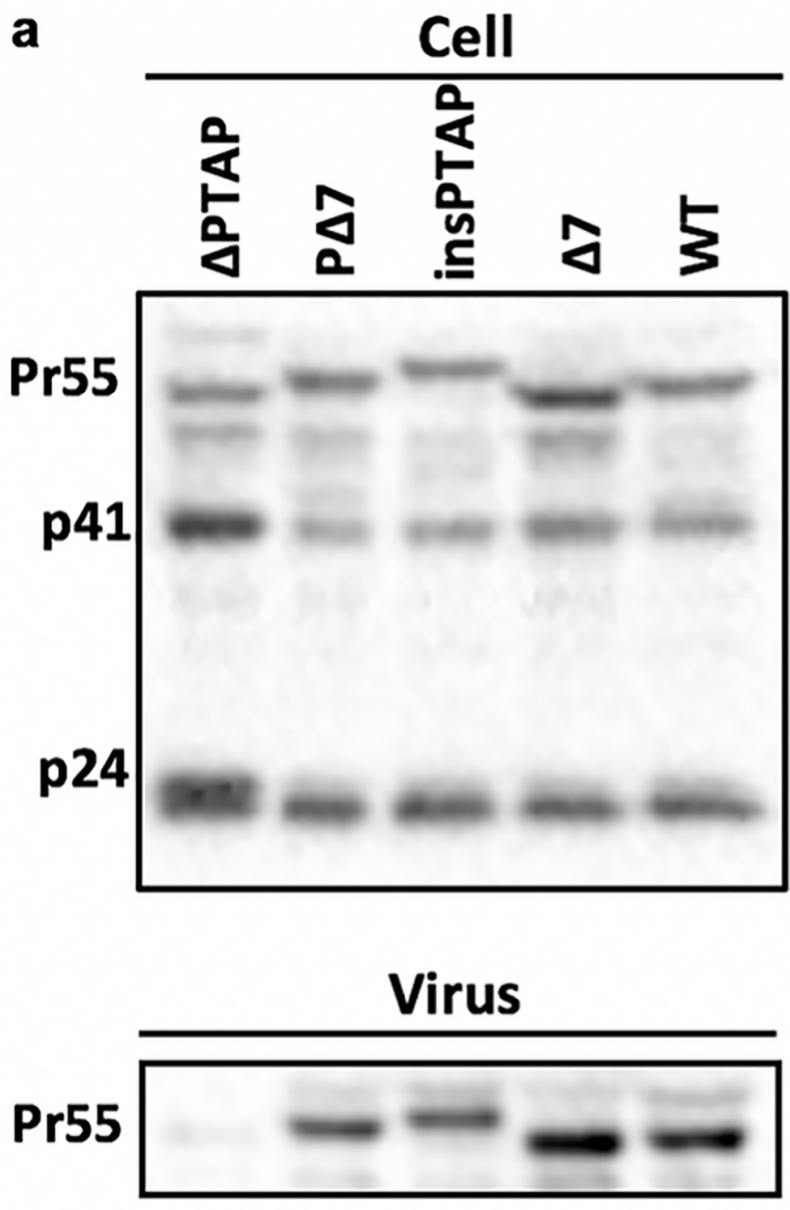

p24

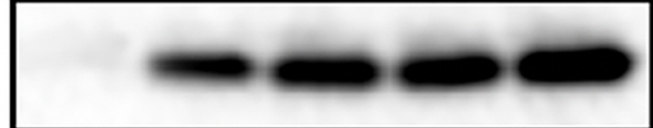

b
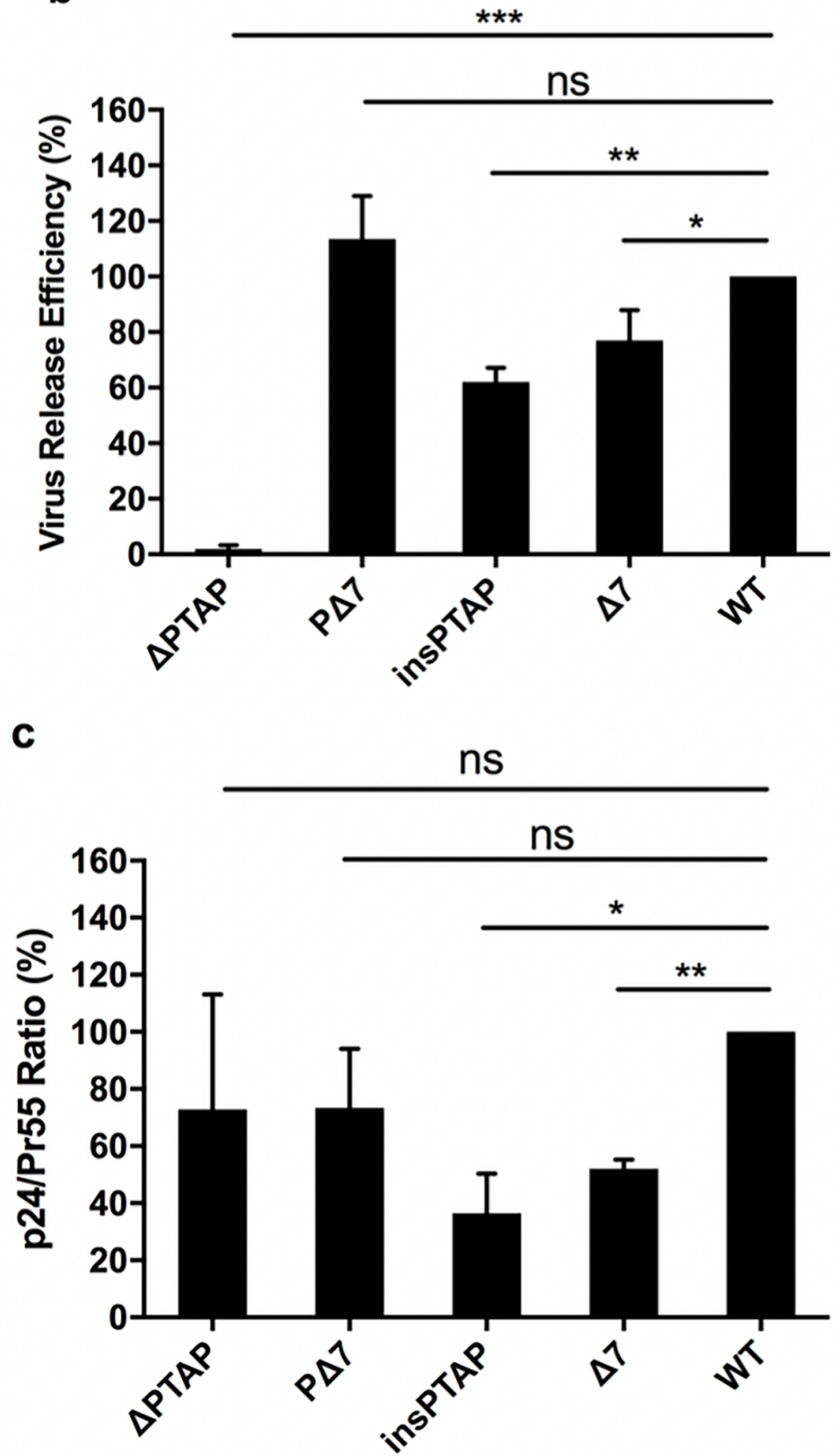

Figure 2

Virus release efficiency and Gag processing. a Western blotting (WB) analysis. 293T cells were transfected with WT pNL4-3 or p6Gag mutants. At $24 \mathrm{~h}$ post-transfection, cell and virus lysates were collected and analyzed by WB with HIV immunoglobulin (HIV-lg). Positions of HIV-1 Gag precursor Pr55Gag, Gag processing intermediate p41 and HIV-1 capsid protein p24 are indicated. b Virus release efficiency. The relative efficiency of virus release was calculated as the amount of virion p24 divided by total Gag (virion p24 + cellular Pr55Gag + cellular p24). c Gag processing. Gag processing was expressed as the ratio of $\mathrm{p} 24$ relative to Pr55Gag in virions. The data were plotted in bar graphs. The efficiency of virus release and Gag processing for WT was set as 100\%. Error bars indicate the standard deviation from more than three independent experiments; ns, not significant. ${ }^{*} P<0.05,{ }^{*} P<0.01$, and ${ }^{* \star *} P<0.001$. 

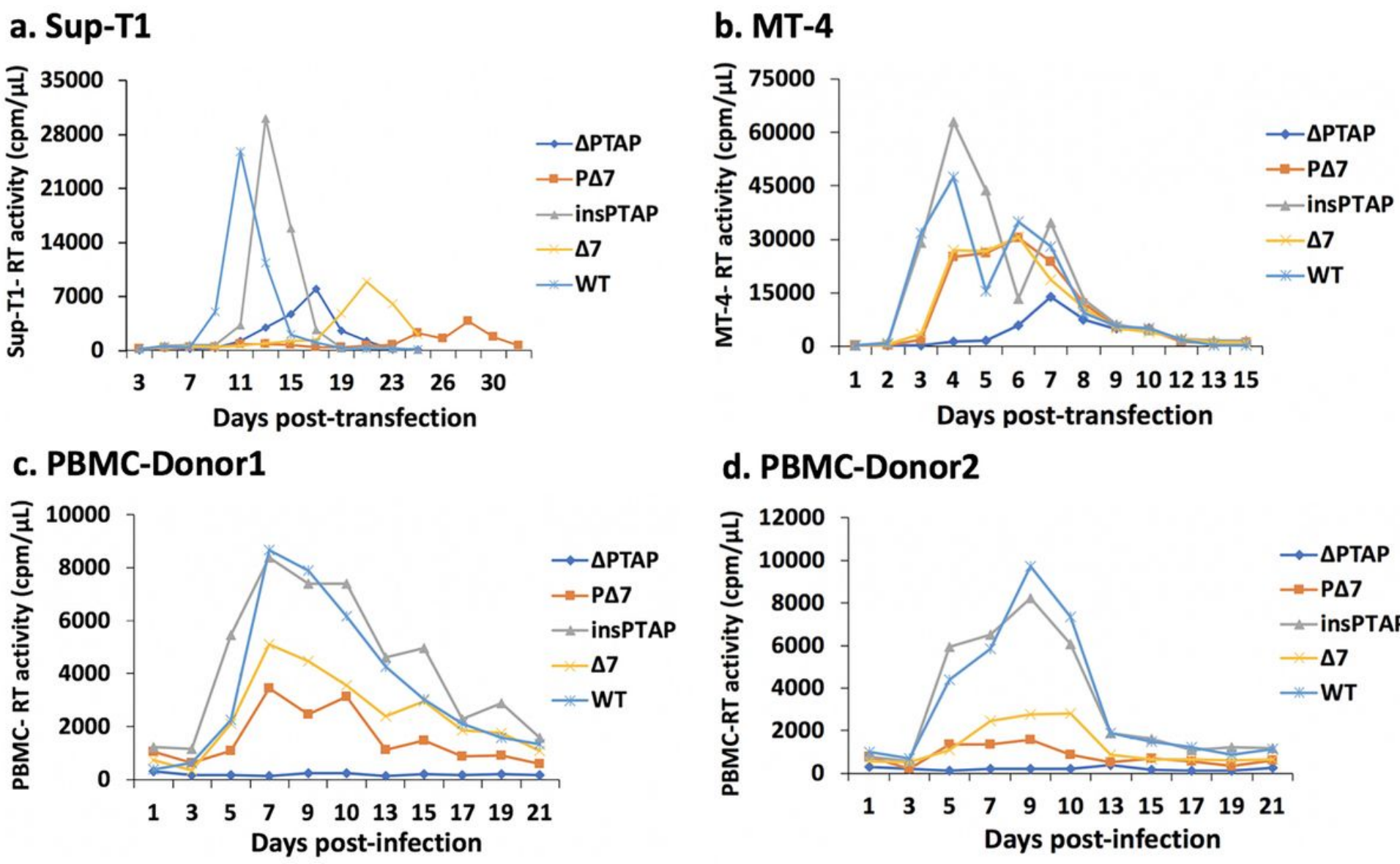

d. PBMC-Donor2

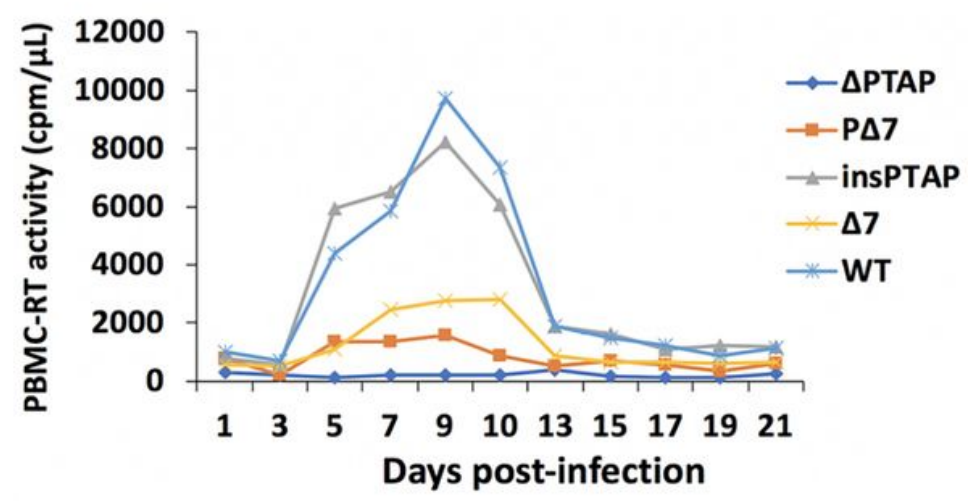

Figure 3

Replication of HIV-1 WT and p6 mutants in Sup-T1 T cells (a), MT-4 T cells (b), and PBMCs (c and d). Both Sup-T1 and MT-4 T-cell lines were transfected with WT or mutant pNL4-3 molecular clones. Cells were split every day or every two days.

Culture supernatants were collected for reverse transcriptase (RT) activity analysis. PBMCs from two donors were infected with virus stocks generated in 293T cells. Cells were split, and culture supernatants collected for RT activity analysis every 2-3 days. Virus replication was monitored by RT activity.

a

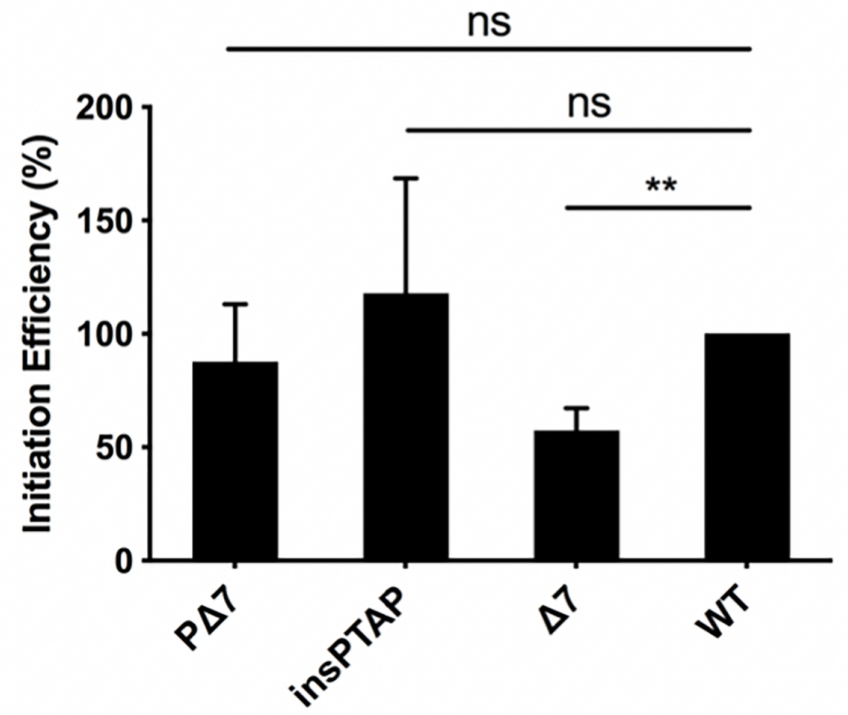

b

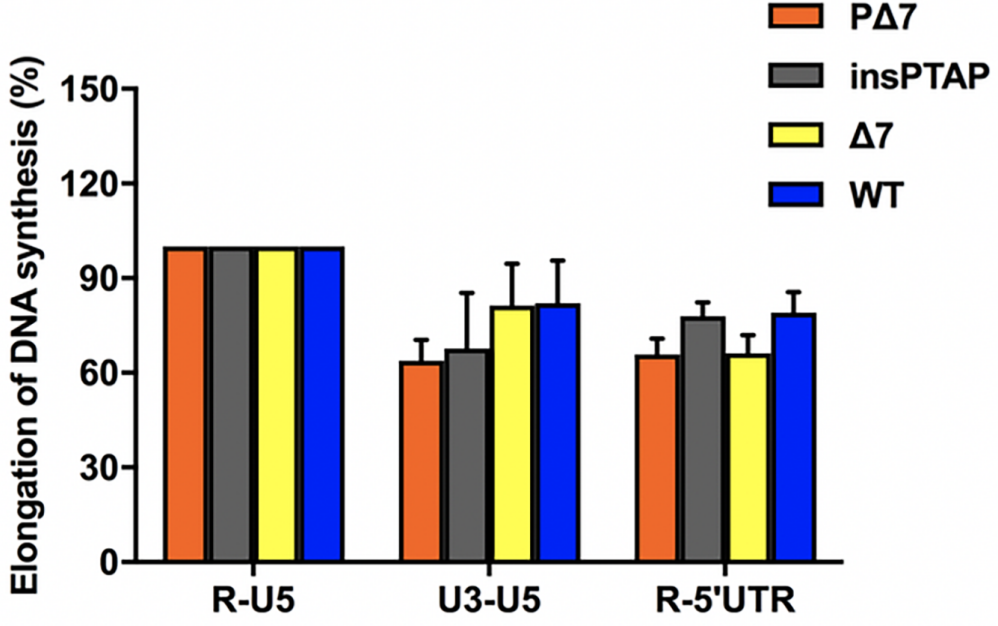

Figure 4 
Effects of p6 mutations on the initiation and elongation of HIV-1 reverse transcription. 293T cells were co-transfected with WT or p6 mutant HIV-1 proviral clones with a VSV-G expressing vector. Pseudotyped virus was harvested and used to infect 293T cells. After $48 \mathrm{~h}$ of infection, cells were lysed followed by DNA extraction. DNA synthesis products R-U5, U3-U5, R-5'UTR were analyzed by real-time quantitative PCR. a Initiation efficiency of reverse transcription in mutant viruses. Initiation efficiency was measured by analyzing the amount of R-U5 DNA. The level of WT virus was set as 100\%. b Relative efficiency of DNA elongation. The level of R-U5 product was set as 100\%, and the amounts of U3-U5 and R-5'UTR products were expressed relative to the R-U5 level. Results from three independent experiments were summarized; error bars indicate standard deviation (SD); ns, not significant. $* * \mathrm{P}<0.01$.

a

Cell

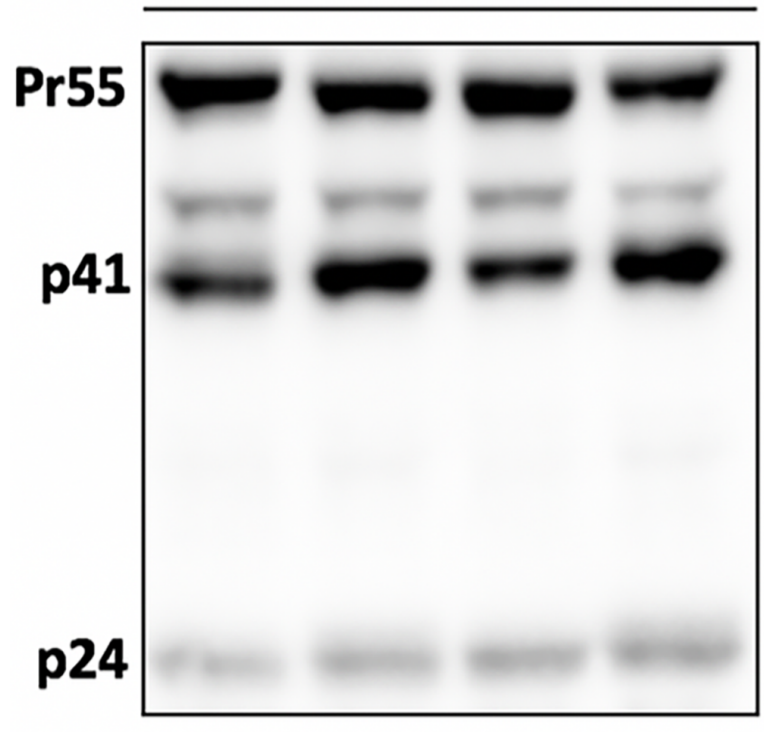

Virus
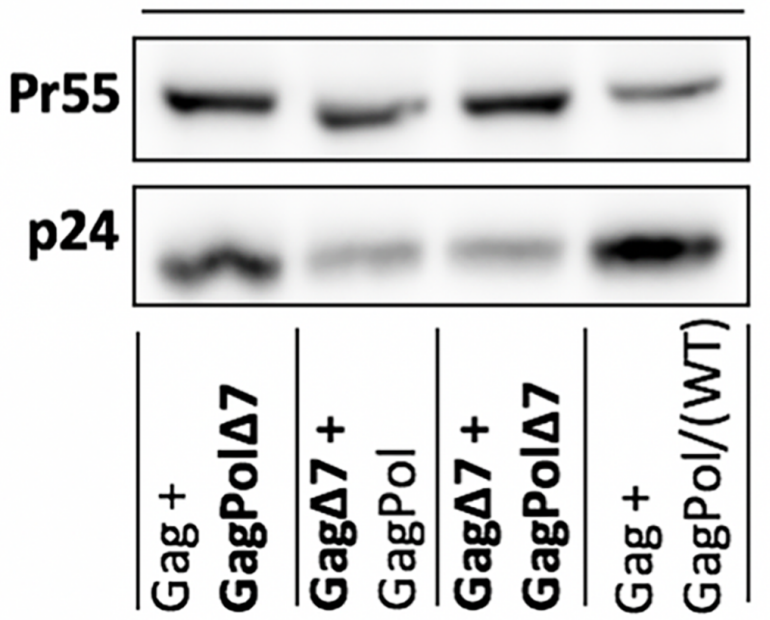

b
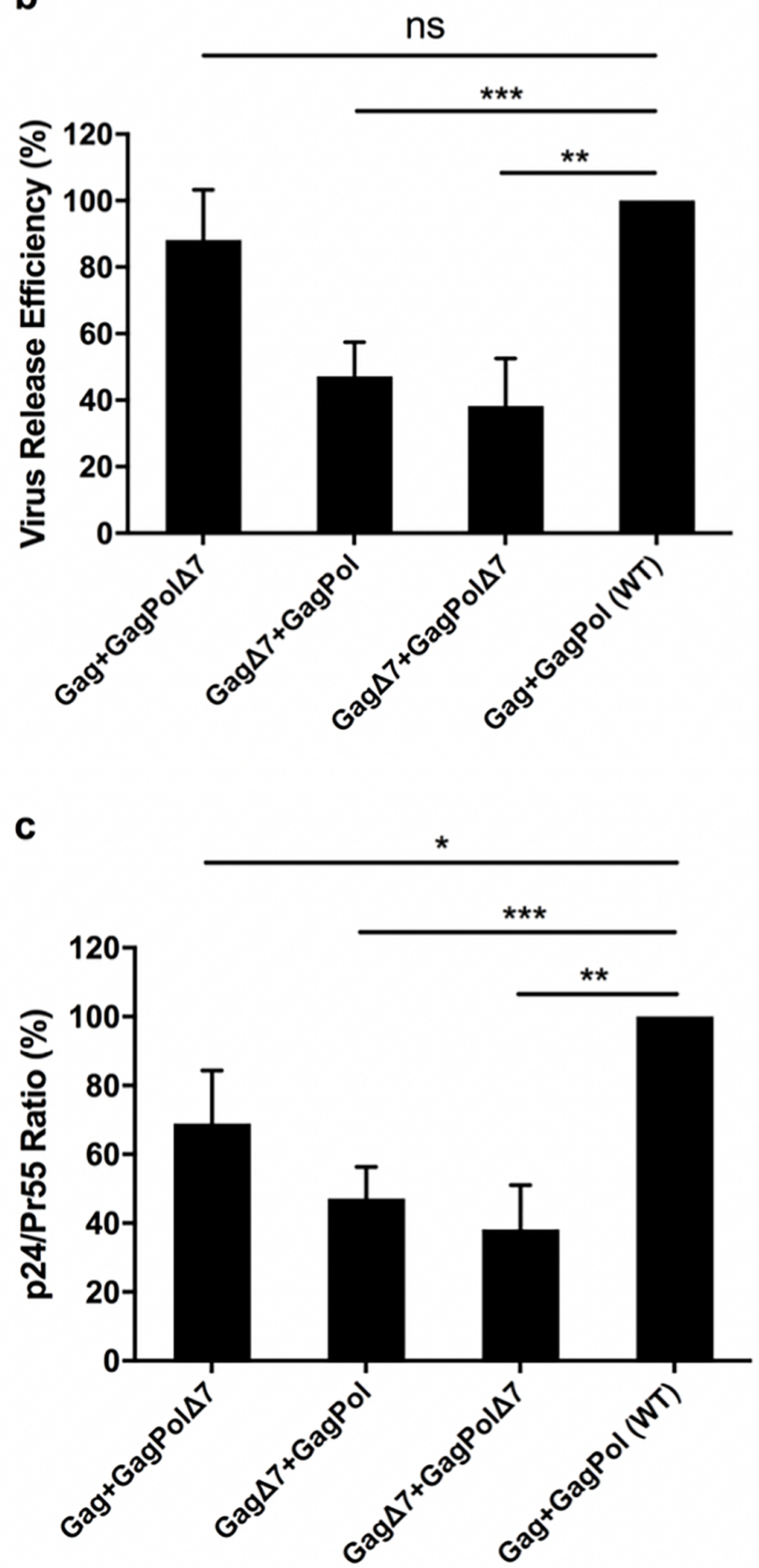

Figure 5

The role of the seven-amino-acid deletion in p6Gag and the overlapping deletion in p6*. Detection of cell- and virionassociated proteins by WB analysis. a 293T cells were co-transfected with HIV-1 proviral clones that encode Gag and GagPol at a ratio of 15:1. Two days post-transfection, virus and cell lysates were harvested and measured by WB. Virus release efficiency (b) and Gag processing (c) were calculated as described in Figure 2. Virus production for WT was set as 
a

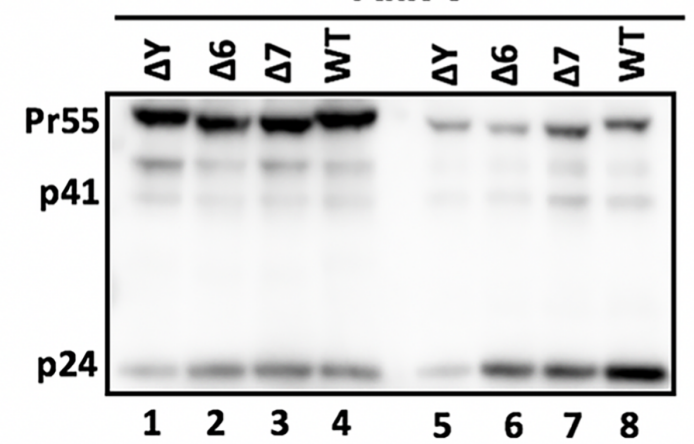

HA-Alix V
- Alix V
+ Alix V

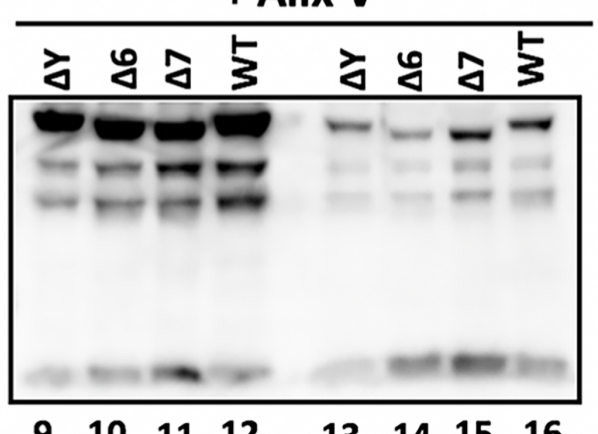

+ Alix V/F676D
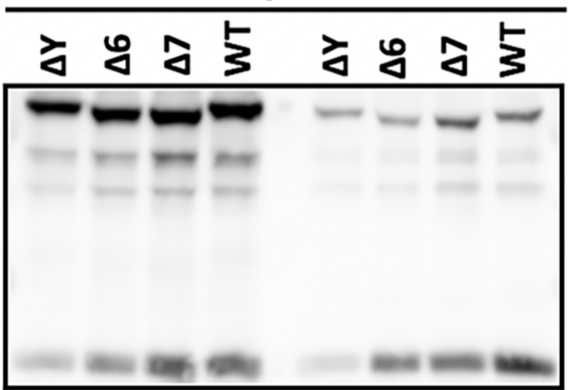

$\begin{array}{llllllll}17 & 18 & 19 & 20 & 21 & 22 & 23 & 24\end{array}$

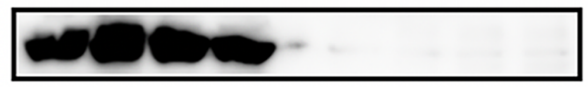

Cell
Virus

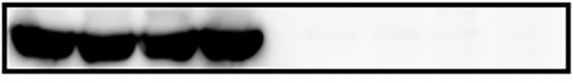

Cell

Virus

C

b

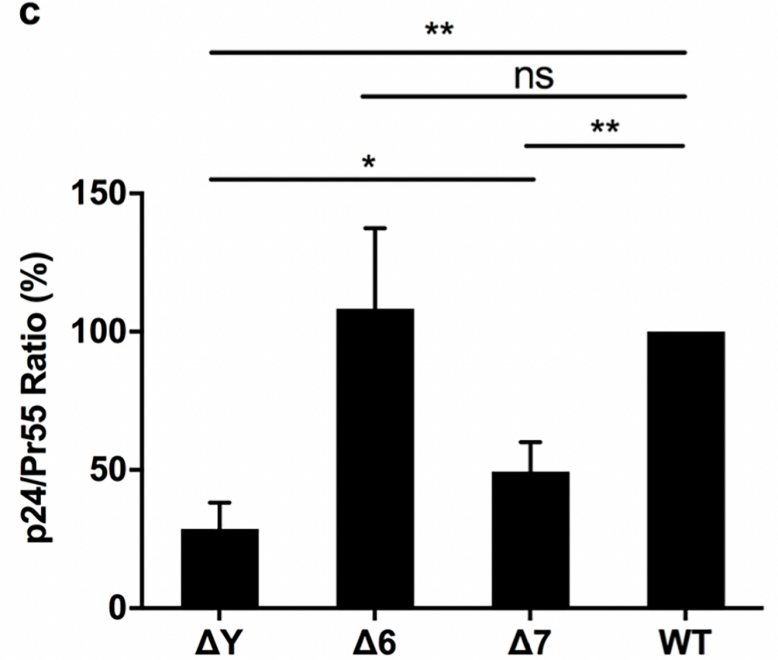

ฮे

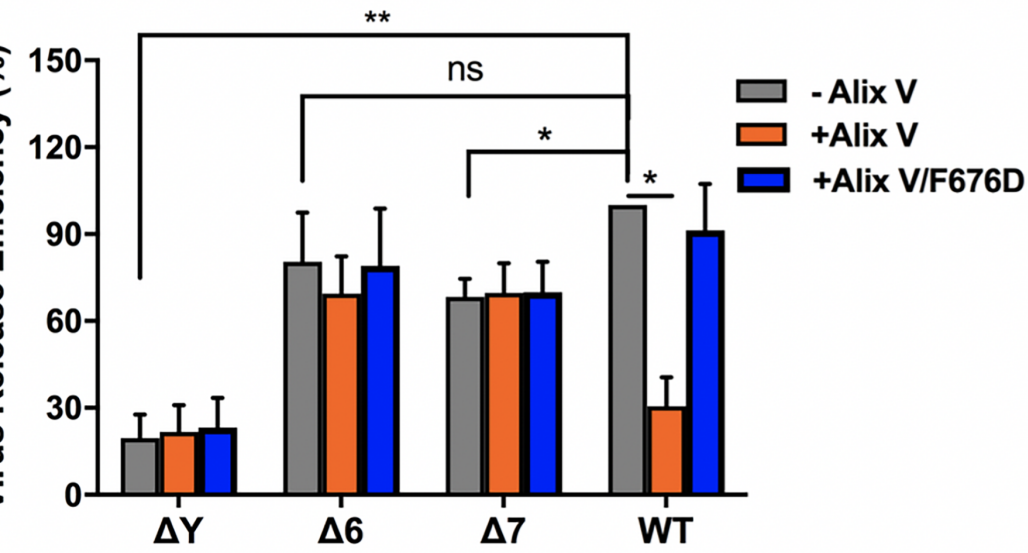

Figure 6

The p6 mutants are resistant to inhibition by Alix V overexpression. a 293T cells were co-transfected with HIV-1 proviral DNA encoding WT Gag or the deletion of the 36th reside $(\Delta \mathrm{Y})$, the 6-aa deletion $(\Delta 6)$, or $\Delta 7$ mutant in p6Gag, together with control plasmid DNA (pcGNM2-Alix) or HA-Alix V or HA-Alix V/F676D expressing vector. At 24h post-transfection, cellassociated and virus-associated proteins were measured by WB. Pr55Gag, p41, p24 and HA-Alix V are indicated. The efficiency of virus release (b) and Gag processing (c) was calculated as described in Figure 2. The levels of WT virus produced in the absence of Alix V (-Alix) was set as 100\%. Error bars show the standard deviation (SD) from 4 experiments. ns, not significant. ${ }^{*} \mathrm{P}<0.05,{ }^{*} \mathrm{P}<0.01$. 